\title{
Index and Compaction Properties of Oil Contaminated Clay Soils in Niger - Delta Region of Nigeria
}

\author{
A. N. Nwachukwu, B. C. Okoro, J. C. Osuagwu, N. L. Nwakwasi, I. C. Onyechere \\ Department of Civil Engineering, School of Engineering and Engineering Technology, Federal University of Technology, Owerri, Nigeria
}

DOI: $10.36348 /$ sjet.2020.v05i02.007 $\quad$ | Received: 21.01.2020 | Accepted: 28.01.2020 | Published: 29.02 .2020

*Corresponding author: Ignatius Chigozie Onyechere

\section{Abstract}

Oil Exploration in Nigeria has contributed greatly towards pollution of the environment especially in the Niger Delta region of the country where most of the oil wells are located. In the process of their operations which include; drilling, refining transportation etc., oil spillage occurs which pollutes land, air and water bodies. This results to the release of dangerous gases into the air. Properties of soils in the contaminated areas are highly affected leading to poor agricultural produce and alteration of geotechnical properties of soils which may adversely affect engineering construction works. This research work examines the effect of crude oil pollution on the geotechnical properties of clay soil. The clay soil was obtained from Engenni Ahoada L.G.A of Rivers, Nigeria. Soil samples were collected at a depth of approximately 2 meters below the ground surface and artificially polluted with crude oil in the ratio of $0 \%, 2 \%, 4 \%, 6 \%, 8 \%, 10 \%, 12 \%$, and $14 \%$ of the dry weight of the soil. The samples were further subjected to various laboratory soil tests to determine their geotechnical properties. The results shows LL, PL, and PI increased from $31 \%, 20 \%$ and $11 \%$ at $0 \%$ contamination to $56 \%, 41 \%$ and $11 \%$ at $14 \%$ contamination. SPGR, BD, and MDD decreased from $2.48,1.33 \mathrm{~g} / \mathrm{cm}^{3}$ and $1.74 \mathrm{~g} / \mathrm{cm}^{3}$ at $0 \%$ contamination to $1.14,0.97 \mathrm{~g} / \mathrm{cm}^{3}$ and $1.35 \mathrm{~g} / \mathrm{cm}^{3}$ at $14 \%$ contamination. OMC increased from $15 \%$ at $0 \%$ contamination to $16.5 \%$ at $14 \%$ contamination. Thus, crude oil pollution affects the geotechnical properties of soil greatly.

Keywords: Clay soil pollution, Geotechnical Properties, Niger Delta region, Crude Oil Pollution, Soil Samples, Oil Spillage.

Copyright @ 2020: This is an open-access article distributed under the terms of the Creative Commons Attribution license which permits unrestricted use, distribution, and reproduction in any medium for non-commercial use (NonCommercial, or CC-BY-NC) provided the original author and source are credited.

\section{INTRODUCTION}

Oil spillage is the accidental discharge of oil to the environment. This may occur during transportation (both land and sea) and as leakages through storage tanks during drilling process [1]. Regardless of the sources of contamination; once it occurs it has deleterious effects on the environment. When it comes into contact with the soil, it alters the physic-chemical properties of the soil. The extent of variation depends on the soil type, the specific composition and quantity of the hydro carbons. The wastes from the petroleum hydrocarbon discharged on the ground finally finds its ways to the soil system and change the properties of the soil like pore fluids, liquid limits, $\mathrm{pH}$ and unconfined compressive strength [2].

Since the beginning of the oil boom in the 1970's, progressive and constant of oil spillage on land and on water bodies have posed serious problems to the environment. Example is the Alaska Exxon Valdez oil spills in 1980 and the recent BP deep water Horizon oil spill in the Gulf of Mexico in 2010 both in USA. The largest oil spill in the world occurred during the gulf war, where an accidental release of petroleum products amounting to approximately 240 million gallons occurred in 1991 [3]. Nigeria is one of the country's worst hit by oil spillage. It is estimated that million tons of oil has been spilled in the Niger Delta ecosystem over the last 50 years. Between 2000 and 2006 a total of 2405 oil spill accidents were documented by the Nigeria Government which represents an alarming rate of 600 oil spills per annum. The rate of oil spill in the country has risen to an unacceptable level. This has led to social and political issues and to a large extent imbroglio in that area such as youth restiveness, corruption, unemployment, alleged neglect etc [4].

Incidence of oil spill has become so rampant in the Oil producing region that made the British broadcasting corporation after visiting Bayelsa and Rivers state in May 2009 described Nigeria as "World Oil pollution capital" [5]. The major causes of oil spillage as presented by [6] are; Corrosion of pipelines and tank accidents (50\%), Sabotage (28\%), Oil 
production and operation (21\%) and Engineering and drills $(1 \%)$.

However, oil exploration has caused major environmental degradation in the area. Major oil spills in the Niger-Delta region include the Gocomb Escravos spill of about 300,000 barrels in 1978, SPDC Forcados terminal of 580,000 barrels and Texaco flemina -5 blowout of about 400,000 barrels in 1980 [7].

When the oil is spilled on water, dispersion occurs, The non solid components evaporate, soluble components dissolve in water, and are chanced by bacterial action before settling to the bottom by gravity. On the terrestrial life, Land is polluted. Mangrove is affected with destruction of fuel woods and Biodiversity. Thus spilled oil is toxic and can cause the death of animals through the prevention of normal feeding, respiration and movement. Despite these harmful effects, Nigerian government has not done much to prevent oil spills or take necessary measures to compensate victims. According to [4], several laws have been promulgated to checkmate the companies and to ensure best environmental practice. The laws have not been enforced oweing to inefficiency on the part of the government. In general, oil contamination due to accidents brings massive damage to the environments. It infiltrates gradually into subsurface environments and pollutes the soil and water system. Hydrocarbon contamination generally affect the soil quality and also alter the physio-chemical properties of oil polluted soil. In a scanty experimental study, it was shown that Oil contamination reduces the permeability, strength and atterberg limits of the soil [8]. The main objective of this study is to determine through laboratory testing the effect of varying percentages of crude oil on selected geotechnical properties of clay soil in the study area which is Akogbologbo in Egene, Ahoada L.G.A of Rivers state, Nigeria. The selected geotechnical properties investigated are atterberg limit, specific gravity, Bulk density and compaction characteristics.

\section{MATERIALS AND METHODS}

The materials used for the study are soil samples (clay) and Crude oil. The soil samples were collected from Akiogbologbo in Engenni Ahoada L.G.A. of Rivers state. Crude oil was collected from Agip oil rig in Bayelsa state.

The samples were air dried and divided into seven parts. Each sample was mixed with varying percentages of oil in the ratio of $2 \%, 4 \%, 6 \%, 8 \%, 10 \%$, $12 \%, 14 \%$ of dry weight of the sample. The samples were kept in an airtight container for two weeks for proper mixing and homogeneity of the mixture. The samples were conveyed to laboratory and subjected to the following soil test based on ASTM standard for soil testing; Atterberg tests, specific gravity, bulk density and compaction test were carried out.

\section{RESULTS AND DISCUSSION}

Fig-1 shows the variation of Liquid Limits (LL) of polluted clay soil with different concentration of crude oil.

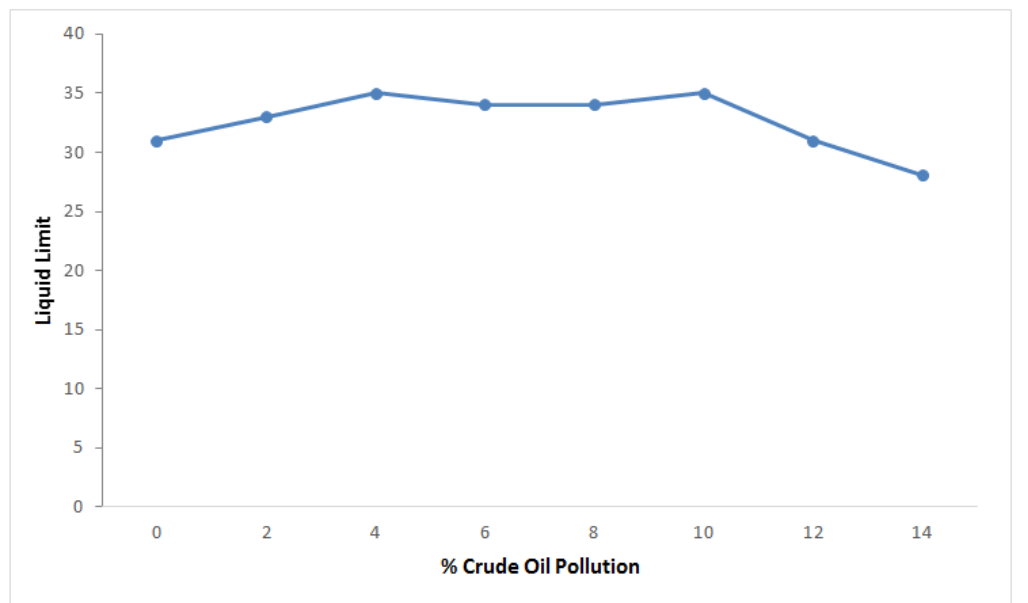

Fig-1: Variation of L.L of polluted clay soil with concentration of crude oil

LL increased from $31 \%$ at $0 \%$ contamination to $35 \%$ at $10 \%$ contamination and decreased to $28 \%$ at $14 \%$ contamination. The increase may have been as a result of micro transformation of the soil due to crude oil addition. It is believed to have caused an inner layer expansion within the clay minerals. The oil may have covered the clay minerals of the soil as well adsorbed water bonded to its surface. This may have increased the thickness of the diffuse double layer. Thus the increase in the Liquid Limit may have been caused by the above reasons.

Fig-2 shows the variation of Plastic Limits (PL) of polluted clay soil with different concentration of crude oil. 


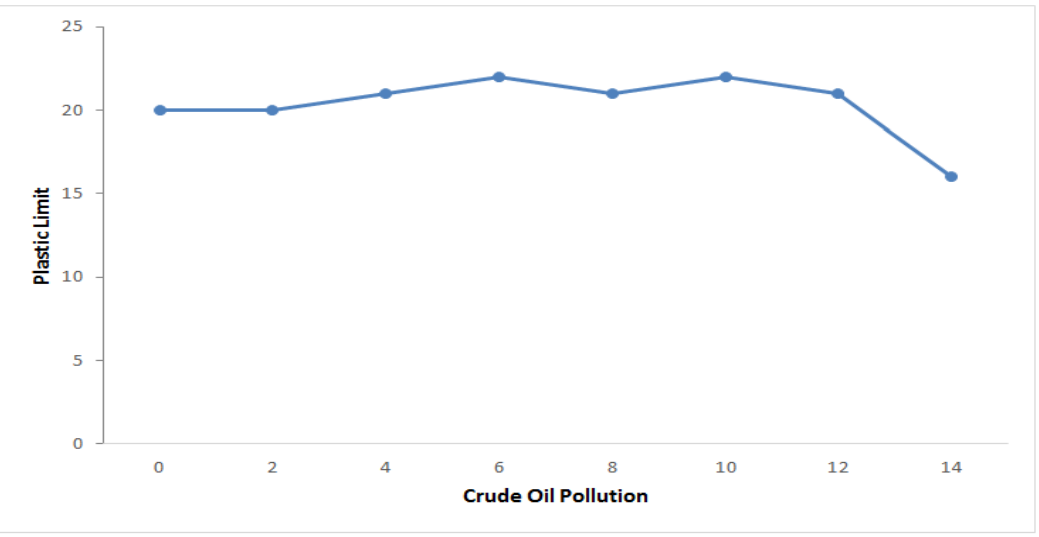

Fig-2: Variation of P.L of polluted clay soil with different concentration of Crude Oil

The PL increased from $20 \%$ at $0 \%$ contamination to $23 \%$ at $10 \%$ contamination and decreased to $15 \%$ at $14 \%$ contamination. The increase may also have been caused by the introduction of crude oil to the soil as seen in the case of LL which caused micro transformation of the soil.
Fig-3 shows variation of Plastic Index (PI) of polluted clay soil with different concentration of crude oil.

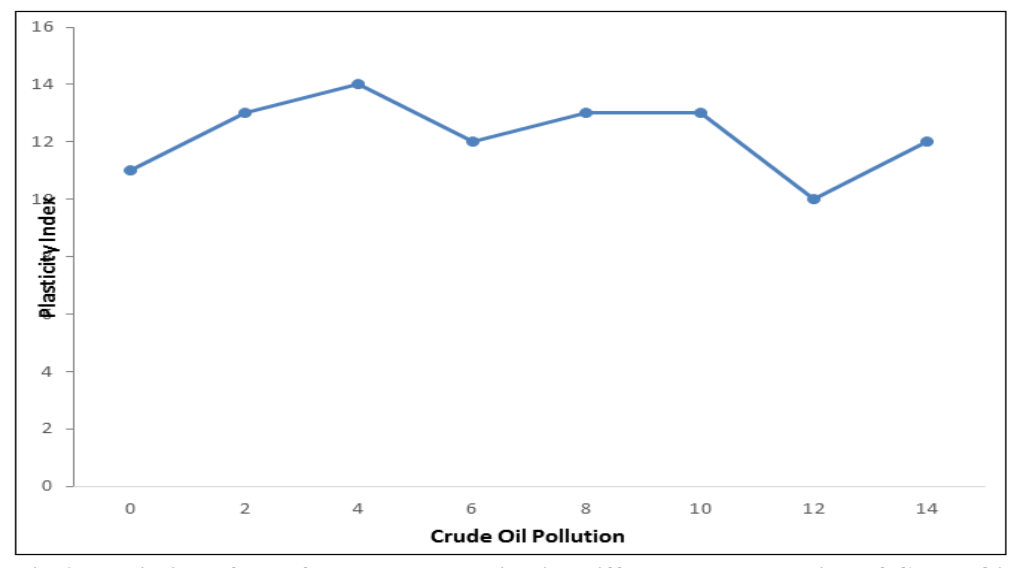

Fig-3: Variation of P.I of polluted clay soil with different concentration of Crude Oil

The PI also increased with the addition of crude oil indicating that the contaminated oil is now less workable.

Again the increase in cohesion of contaminated clay must have been caused by the increase in bonding by oil particles. Hence additional water would be needed to cause change in consistency level for the thick layer of contaminated soil.

Fig-4 shows the variation of Specific Gravity of polluted clay soil with different concentration of crude oil

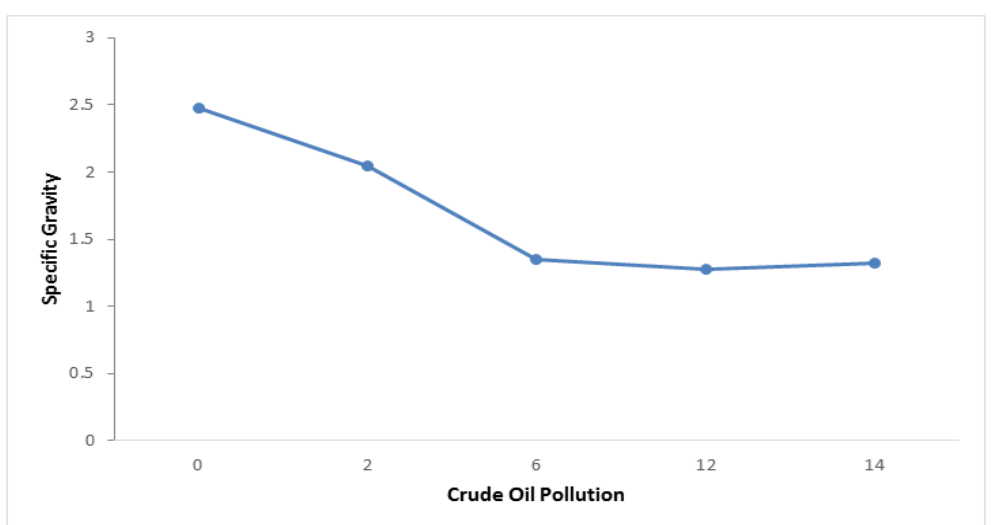

Fig-4: Variation of Specific Gravity of polluted clay soil with different concentration of Crude oil 
The specific gravity of the soil was found to decrease progressively as the percentage of crude oil contamination is increased. It decreased from 2.48 at $0 \%$ contamination to 1.32 at $14 \%$ contamination, which represents about $47.6 \%$ decrease. This again maybe as a result of specific gravity of crude being lower than that of the soil, which has caused the specific gravity of the contaminated soil to decrease.

Fig-5 shows the variation of Bulk Density of polluted clay soil with different concentration of crude oil.

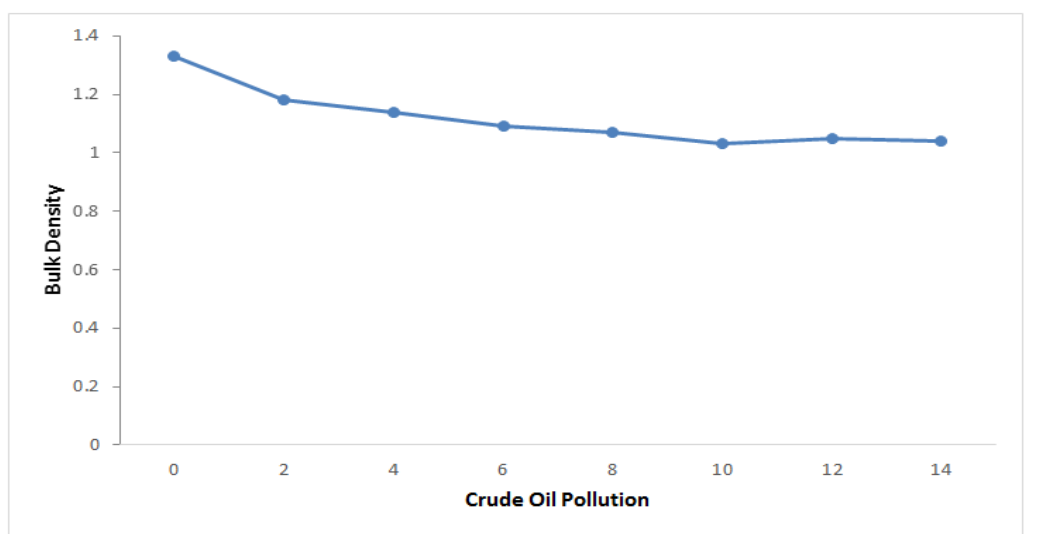

Fig-5: Variation of Bulk Density of polluted clay soil with different concentration of crude oil

Fig-5 shows result of bulk density of clay contaminated with crude oil. The bulk density decreased from $1.33 \mathrm{~g} / \mathrm{cm}^{3}$ at $0 \%$ contamination to $1.04 \mathrm{~g} / \mathrm{cm}^{3}$ at $14 \%$ contamination which represents about $22 \%$ decrease. The decrease is as a result of addition of crude oil which reduced the bulk density.
Fig-6 shows the variation of Maximum Dry Density of polluted clay soil with different concentration of crude oil.

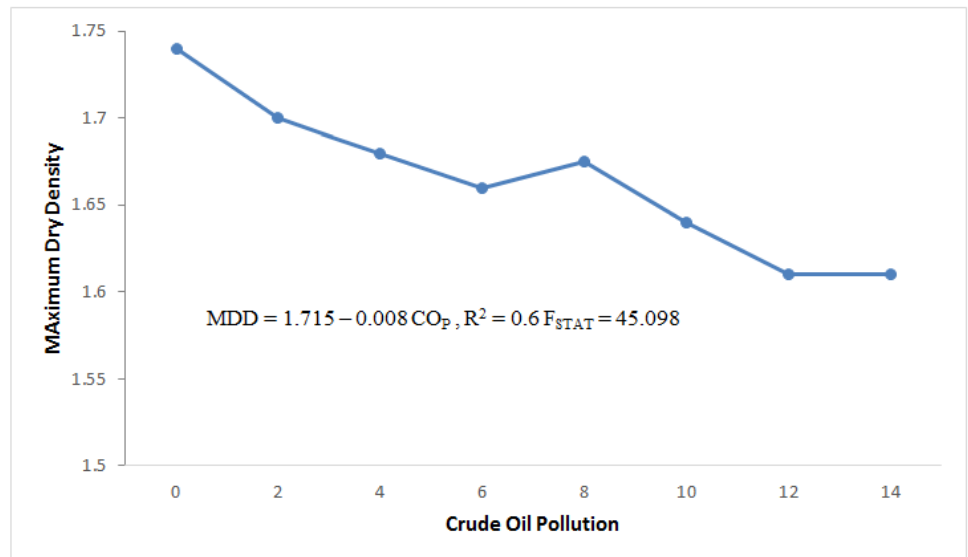

Fig-6: Variation of Maximum Dry Density of polluted clay soil with different concentration of Crude oil

With increase in crude oil pollution there is progressive reduction in maximum dry density (MDD). The MDD decreased from $1.74 \mathrm{mg} / \mathrm{m} 3-1.61 \mathrm{mg} / \mathrm{m} 3$ which represents 7.5 percentage reduction. The reduction in MDD may be due to increase in the diffusible layer which may have made compaction more difficult, thus applying the same energy, the uncontaminated soil has high MDD. The contaminated soil are less packed together. This may be responsible for the reduction in the MDD. Also the reduction in the
MDD reflects the effect of lubrication imparted by the soil due to the presence of crude oil and diesel. Finally, it may be due to the natural strength of soil which allows it to develop minimal value. The results are in agreement with [9].

Fig-7 shows the variation of Optimum Moisture Content of polluted clay soil with different concentration of crude oil. 


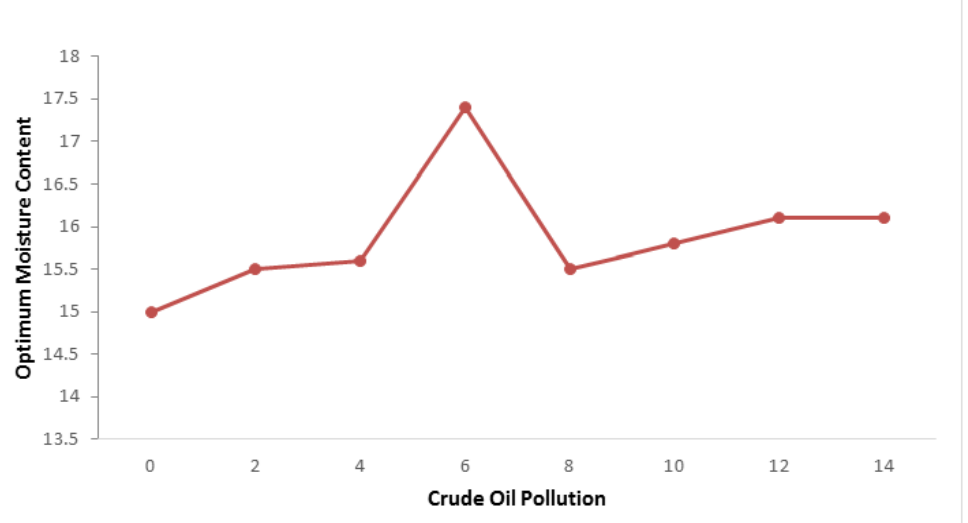

Fig-7: Variation of optimum moisture content of polluted clay soil with different concentration of Crude oil

The optimum moisture content increased steadily from $15 \%$ at $0 \%$ contamination to $17.4 \%$ at $6 \%$ contamination before it started decreasing but did not decrease below $15 \%$.

\section{CONCLUSION}

Change in the geotechnical parameters of polluted clay soil was investigated. The contamination was in the ratio of $2 \%, 4 \%, 6 \%, 8 \%, 10 \%, 12 \%$ and $14 \%$ of dry weight of the soil samples with $0 \%$ as the control. The value of LL, PL and PI increased steadily from uncontaminated sample ( $0 \%$ contaminator) to $14 \%$ contamination. The specific gravity and bulk density also shows constant decrease as a result of the pollution for crude oil.

In case of the compaction characteristics, the maximum dry density (MDD) decreased from $0 \%$ contamination to $14 \%$ contamination. Optimum moisture content (OMC) increased from $0 \%$ contamination to $6 \%$ contamination and started decreasing again but it did not get below the value at $0 \%$.

It is very clear and obvious that from this study, crude oil pollution has adverse effect on geotechnical properties of soil since those properties which were altered contribute immensely to the shear strength of engineering soils. Finally proper investigation should be carried out and appropriate remedial measures applied to reduce the negative impact to an acceptable level before such soils can be used for building and civil engineering construction works.

\section{REFERENCE}

1. Ayanova, E. (2012). Oil pollution and international marine environmental law. Journal of Information Technology. 12(8), 29-40.

2. Talukda, D. K., \& Saika, B. D. (2013). Effect of crude oil on some consolidation properties of clay soil. International Journal of Engineering Technology and advanced Engineering. 3, 117120.

3. Tolu, U. S., Kolars, A. Y., \& Serikan B. K. (2013). Geotechnical properties of oil contaminated Kuwait sand. Journal of Geotechnical Engineering ASCE. 121(5), 407-412.

4. Egwu, S. A. (2012). Oil spill control and management. Petroleum Technology Development Journal. 1, 1-6

5. Nwilo, C. P., \& Badejo, T. O. (2013). Management of oil spill dispersal along the Nigerian coastal areas. ISPRS congress 2004, Istanbul, Turkey.

6. Nwilo, C. P., \& Badejo, T. O. (2009). Laboratory studies on the influence of crude oil spillage on lateritic soil shear strength, a case study of Niger Delta area of Nigeria. Journal of Earth Science and Geotechnical Engineering. 2(3), 73-83.

7. Nwilo, C. P., \& Badejo, T. O. (2005). Oil spill problems and management in the Niger-Delta. International Oil spill conference Miami Florida, USA.

8. Mashala, K., Charkhabi, A. M., \& Tajik, M. (2006). The effects of crude oil contamination on Geotechnical properties of Bushe in coastal soils in Iran. Journal of the Geotechnical Society London. 214.

9. Pandey, A., \& Bind, Y. K. (2014). Effects of oil contamination on geotechnical properties of alluvial soil Naini, Allahabad. International Journal of Innovative Technology and Exploring Engineering, 3(8), 39-42. 